\title{
THE UNPUBLISHED LIKENESS OF CYPRIAN NORWID'S ORIGINAL BIRTH CERTIFICATE
}

In the conclusion to the article Ślady Norwidów w Dabrówce, Waldemar Pałys claims that "the presented documents seem to constitute the entirety of Norwid's traces preserved in his family parish." ${ }^{1}$ Fifteen years later, however, it becomes necessary to verify this claim out of two reasons. First, the archive of the Warszawa-Praga Diocese was established in 2007, gathering documents that include the aforementioned parish records from Dąbrówka. Second, as it has recently turned out, one citizen of the Dąbrówka district is in possession of a slight portion of the parish archive, which became dispersed much earlier, including one document of special interest to all scholars of Cyprian Norwid.

In volume eight of the magazine "Chimera", devoted to the memory of Norwid, Przesmycki (Miriam) writes:

In Norwid's archive, generously donated to us by W. Gasztowt and so often invoked here, we have found a bundle of the poet's private documents, including: (1) a hand-painted parchment titled "Excerptt (sic) Genealogij Starożytnego Domu Urodzonych Norwidów" ["Excerpt from the Genealogy of the Ancient House of the Norwids"], issued in 1811 to the requisitioning party by the gentry genealogical commission operating in the Mińsk province, basing on its own genealogical records; (2) a hand-written note ascertaining the membership of Jan Norwid (the poet's father), as third-degree member of "de l'Aigle Blanc," one of the twenty-three masonic lodges subordinate to the Grand Lodge Astrée à l'O in St. Petersburg; (3) original proof of the poet's confirmation, granting him the name "Kamil" by Cardinal Franzoni in Rome in 1845 ("patrinus fuit Illumus D. Carolus Comes Krasiński"); and finally, (4) the poet's birth certificate, which states his real date of birth to be 24 September $1821^{2}$, along with a French trans-

${ }^{1}$ W. PaŁys, Ślady Norwidów w Dąbrówce, "Studia Norwidiana” 20-21: 2002-2003, p. 166.

${ }^{2}$ Miriam's remark (made with satisfaction) that the document quoted below finally settles the question of the poet's date of birth stems from divergences in sources available at the time. For 
lation of this document, made probably for use abroad though not confirmed by any office. This birth certificate, made on "stamp-ready" paper, containing both watermarks and an official stamp, is quoted below in full:

Warsaw Governorate (revenue stamp 7,5 kopek) district of Stanisławów

Extract from the Birth Records of the Dąbrówka Parish Church.

No. 86, Sheet 19, Głuchy Village. On this $1^{\text {st }}$ day of October year 1821 at ten o'clock in the morning, before me, Father Jan Kanty Matliński, the parish priest of Dąbrówka, civil registrar in the Dąbrówka commune, district of Stanisławów, province of Mazovia, personally appeared the Most Honourable Jan Norwid, aged thirty seven, Knight of the Order of Malta, Lord of Laskowo Głuchy, resident therein, and presented a male infant born on the twenty fourth day of last month at eight o'clock in the evening in Laskowo Głuchy, in his own house under number one, and declared that the child was the son of his and his wife, the Most Honourable Ludwika Zdzieborska, aged twenty two, and expressed their wish to name him Cypryan, Xawery, Gierard and Walenty. After making the above declaration and presentation of the above child in the presence of the Most Honourable Cypryan Szukiewicz, aged forty one, President of the Court of Appeals in Grodno, resident in Warsaw, and Xawery Dybowski, aged fifty, Marshal of the district of Węgrów and Lord of Dębinki and Ceranów estates, resident in Dębinki, this Act was read out to the appearing parties and signed by me and the father of the child and two witnesses. Jan Norwid, Cypryan Szukiewicz, Xawery Dybowski, Father Jan Kanty Matliński, the parish priest of Dąbrówka.

example, different dates were provided in obituaries published after Norwid's death. The author of the obituary for "Dziennik Poznański" (no. 119, 29 May 1883) admits that "[i]t was impossible to establish his exact date of birth; nevertheless, there is consensus that he must have been over sixty, which means that he was born around 1820" (after: Z. TrojanowiczowA, E. LiJEwsKA, Kalendarz życia i twórczości Cypriana Norwida, vol. 2: 1861-1883, p. 785). Next, obituaries published in Gazeta Warszawska (no. 120, 2 June 1883) and Rola (no. 23, 9 June 1883) inform that Norwid was born in 1825 (see: ibid., p. 791, 793). Several other obituaries provide the information that the poet was fifty-nine when he died, thus moving his date of birth back to 1824 (see: ibid., p. 787, 792, 796). On the other hand, Kurier Paryski (15 June 1883) mentions the design of Norwid's gravestone, which was supposed to be erected by the residents of Euvre de Saint Casimir, quoting the planned inscription with the year 1822 (see: ibid., p. 764). Two biographical entries published when Norwid was still alive - in Brockhaus Konversations-Lexicon and in Grand Dictionnaire Universel du XIXe siècle by Pierre Larousse - provide the date 1842 (see: ibid., pp. 330-331, 551). The same year is indicated in a letter from Eliza Thiébault Lubomirska to Norwid, where she comments on his crossing the "unfortunate Rubicon of forty years" (see: ibid., p. 202). Juliusz Wiktor Gomulicki notes that this letter constitutes "an interesting echo of his [Norwid's] personal myth" (J.W. GoMULICKI, "Addenda et corrigenda," PWsz XI, 608. Clearly, Gomulicki refers to the famous sentence from Autobiografia artystyczna: "He was born in Masovia in the village called Laskowo, several miles outside Warsaw, at the time when Noël Byron was dying in Greece, and he still does not know which of these two events is sadder" (PWsz VI, 556). Thus, the poet himself linked his date of birth with the date of Byron's death, i.e. the year 1842. Echoes of this self-fashioned "personal myth" are also discernible in some of the abovementioned sources, and have significantly influenced the state of knowledge among the early scholars of Norwid, including Zenon Przesmycki. 
Certified to be a true copy of the relevant records of the Church in Dąbrówka on 29 April 1846 by

[place for the seal] ${ }^{3}$

Father Fr. Zanaszewski assistant curate in the Dąbrówka Parish Church

As is clear, although Przesmycki initially wrote about the poet's "birth certificate," he had access only to a copy made in 1846, from which he quotes. Juliusz Wiktor Gomulicki published a photocopy of this same document many years later in the last volume of Pisma wszystkie ${ }^{4}$ as well as in a separate edition of the volume's encyclopaedic part. ${ }^{5}$ Interestingly, both in descriptions of illustrations and in the explanatory section "Dokumentacja ilustracyjna. Objaśnienia" the editor refers to this document as "Świadectwo urodzenia Cypriana Norwida, 1821" ["Birth certificate of Cyprian Norwid, 1821"] ${ }^{6}$, although in a further comment he provides its real title: "Wyciąg z Ksiądz Urodzeń Kościoła Parafii Dąbrówka" ["Excerpt from the Register of Births at the Parish Church in Dąbrowka"], explaining that it was made "at the request of the poet, who stayed at that time in Berlin and was completing passport-related formalities."7 One hint at a possible explanation of this surprising inconsistency can be inferred from a close reading of a document published under the title "Świadectwo urodzenia Cypriana Norwida" ["Birth certificate of Cyprian Norwid"] in Kalendarz biograficzny Cypriana Norwida, contained in the same, eleventh volume of Pisma wszystkie:

G ł u chy Village. On this $1^{\text {st }}$ day of October year 1821 at ten o'clock in the morning, before me, Father Jan Kanty Matliński, the parish priest of Dąbrówka, civil registrar in the Dąbrówka commune, district of Stanisławów, province of Mazovia, personally appeared the Most Honourable Jan Norwid, aged thirty seven, Knight of the Order of Malta, Lord of Laskowo Głuchy, resident therein, and presented a male infant born on the twenty fourth day of last month at eight o'clock in the evening in Laskowo Głuchy, in his own house under number one, and declared that the child was the son of his and his wife, the Most Honourable Ludwika Zdzie-

${ }^{3}$ Z. P. [Zenon Przesmycki], Z notat i dokumentów o C. Norwidzie, "Chimera" 8 (1904), vol. 22/23/24, pp. 437-438. The document is currently held at the Polish National Library, catalogue no.: Rps 6293 IV.

${ }^{4}$ See: PWsz XI, figs. 3-4. Earlier, Gomulicki would only describe the document in a catalogue of the 1946 exhibition. See: Cyprian Norwid. Wystawa w 125 rocznice urodzin. Katalog, Warszawa 1946, item 5, p. 10.

${ }^{5}$ See: J.W. Gomulicki, Cyprian Norwid. Przewodnik po życiu i twórczości, Warszawa 1976.

${ }^{6}$ See: PWsz XI, 328. It was wrongly assumed that the number 86 in the document is the excerpt number, whereas in fact it is the number of the poet's birth certificate.

${ }^{7}$ Ibid. In footnotes to the document Gomulicki references the photocopy in the following way: "See the likeness of this certificate, which the poet carried with him around the world: figs. 3 and 4 (and explanations)" (PWsz XI, 159). 
borska, aged twenty-two, and expressed their wish to name him Cyprian, Ksawery, Gierard and Walenty. After making the above declaration and presentation of the above child in the presence of the Most Honourable Cyprian Szukiewicz, aged forty one, President of the Court of Appeals in Grodno, awarded with many orders, resident in Warsaw, and Ksawery Dybowski, aged fifty, Marshal of the district of Węgrów and Lord of Dembinki and Ceranów estates, resident in Dembinki, this act was read out to the appearing parties and signed by me and the father of the child and two witnesses.

Jan Norwid - Cyprian Szukiewicz - Xawery Dybowski - Jan Kanty Matliński, the parish priest of Dąbrówka, registrar ${ }^{8}$

Most differences between the text quoted by Przesmycki and the one from Gomulicki's edition regard the obvious modernization of orthography (especially with regard to capital letters) and punctuation. However, there are five differences of another character. The less prominent are: the change of spelling with regard to the parish seat from "Dębinki" to "Dembinki," and the lack of the word "father" before the name "Jan Kanty Matliński" in the list of those who signed the act. The other three are much more important and highly symptomatic.

First, Gomulicki expands the characteristic of Cyprian Szukiewicz by adding the phrase "awarded with many orders." Second, he expands the abbreviations in the list of signatories ("Prob[oszcz]"; "Dąbr[owski]"; "U[rzędnik]"). Third, the document ends, in this version, with the specification of the official function of father Matliński as parish priest, or "registrar." The text published in Chimera lacks these elements; moreover, they are not to be found on the photocopy of the birth certificate's copy, which means that omitting them was not a mistake on the part of Miriam, who used this exact copy. ${ }^{9}$ It seems difficult to view such far-reaching yet few differences as simple mistakes committed in the process of copying documents. The reason must be different: most probably, Gomulicki saw a different document or its faithful copy. Perhaps he obtained it earlier, but lost it while preparing the publication of Pisma wszystkie (the parish archive was dis-

\footnotetext{
${ }^{8}$ PWsz XI, 26-28.

${ }^{9}$ Interestingly, authors of the calendar of Norwid's life and work, who quote passages from the discussed document, declare that they are following Przesmycki's edition, but in fact draw on both versions, compiling the decisions of Miriam and Gomulicki, also introducing their own modifications. For example, just like Przesmycki they use the noun "ksiądz" [father, priest] in the list of people who signed the document, and just like Gomulicki they characterize Szukiewicz as having been "awarded with many orders," adding at the end the term "registrar," though without abbreviations. Finally, in an earlier text they change the spelling of capital and small letters (although it is probably a printing error that the text uses the word "stawiającym" instead of "stawającym" in the passage "akt niniejszy stawiającym [sic!] przeczytaliśmy"). See: Z. TROJANowiczowa, Z. DAmBeK, Kalendarz życia i twórczości Cypriana Norwida, vol. 1: 1821-1860, Poznań 2007, pp. 3-4.
} 
persed several times and partially damaged), which resulted in publishing a text that differs in several places from the copy presented (as a photocopy) in Pisma wszystkie. This hypothesis is confirmed by the poet's original birth certificate, luckily preserved by a private person.

The document is part of a slightly damaged sewn sheet that constitutes a significant portion of vital records from the Dąbrówka parish from 1821. The preserved passage begins with Act no. 68 from June of that year, and bears a contemporary inscription at the top of the page, done in red and partially blue ballpoint: "1821" (see fig. 1). The page containing the poet's birth certificate has slightly damaged edges and is partially blotted with ink; however, the text is entirely legible (see fig. 2). What draws attention is the very careful and decorative handwriting. Unlike most entries in the volume, the document was written entirely in hand by the parish priest himself - father Jan Kanty Matliński (as confirmed by comparisons with handwriting samples from the many signatures made by father Matliński under acts made by others and contained on neighbouring pages). Clearly, the act was also signed in person by other attendees, including Jan, the poet's father. In the case of many other acts, however, the situation is different, the signature of the parish priest being preceded with the formula: "This act has been read out aloud to all in attendance and, in case they could not write, was signed by us" (see fig. 3 , acts 83 and 84 , and fig. 2, act 87).

Upon closer inspection it becomes clear that the presented original birth certificate is the one that Gomulicki relied on in his edition. Although he modernized orthography and punctuation, unjustifiably linking the dating formula with the first sentence, and disregarding the word "ksiądz" [father (priest)] (written using the abbreviation "X") before the signature of the parish priest, all of the above significant departures from the text edited by Przesmycki are confirmed. One notable curiosity is the addition "and awarded with many orders" in reference to Cyprian Szukiewicz, initialled by father Matliński (with his last name only). As is clear, this was added after the act was made and signed, probably at the request of Szukiewicz himself. It is probably due to its untypical placement that the copy made twenty-five years later by Father Franciszek Zamaszewski does not take it into account (just like it omits the specification "registrar"), as a consequence of which it was left out from the version published by Przesmycki.

Finally, it is worth to mention that the volume concludes with an alphabetic register comprising three sections - "births," "marriages" and "deaths" - containing information about people whose personal details have been entered into given acts alongside with the numbers of these documents and the page numbers where they can be found (see fig. 4). Fortunately, the page with names beginning with the letter "n" has been preserved (see fig. 5). 


\section{REFERENCES}

Cyprian Norwid. Wystawa w 125 rocznicę urodzin. Katalog, Warszawa 1946.

PaŁys W., Ślady Norwidów w Dąbrówce, "Studia Norwidiana” 20-21: 2002-2003, pp. 163-182.

Trojanowiczowa Z., LiJewska E., Kalendarz życia i twórczości Cypriana Norwida, vol. 2: 1861-1883, Poznań 2007.

Trojanowiczowa Z., Dambek Z., Kalendarz życia i twórczości Cypriana Norwida, vol. 1: 1821-1860, Poznań 2007.

Gomulicki J.W., Addenda et corrigenda, [in:] PWsz XI.

Gomulicki J.W., Cyprian Norwid. Przewodnik po życiu i twórczości, Warszawa 1976.

Z.P. [Przesmycki Zenon], Z notat i dokumentów o C. Norwidzie, "Chimera" 8 (1904), vol. 22/23/24, pp. 419-453.

\section{$\mathrm{S}$ u m m a r y}

The article presents the unpublished original of Cyprian Norwid's birth certificate, which was found in Dąbrówka parish records, and examines archival documents as well as Norwid's writings, specifically ones where the poet makes references to his birth date, taking also into account the findings of Zenon Przesmycki and Juliusz Wiktor Gomulicki.

Key words: birth certificate; Dąbrówka; Father Jan Kanty Matliński.

Tomasz Korpysz is Professor at the Faculty of Humanities in the Cardinal Stefan Wyszyński University in Warsaw, and head of the Cyprian Norwid Language Dictionary Division at the University of Warsaw. Address: Dewajtis 5, 01-815 Warszawa, e-mail: t.korpysz@uksw. edu.pl. 


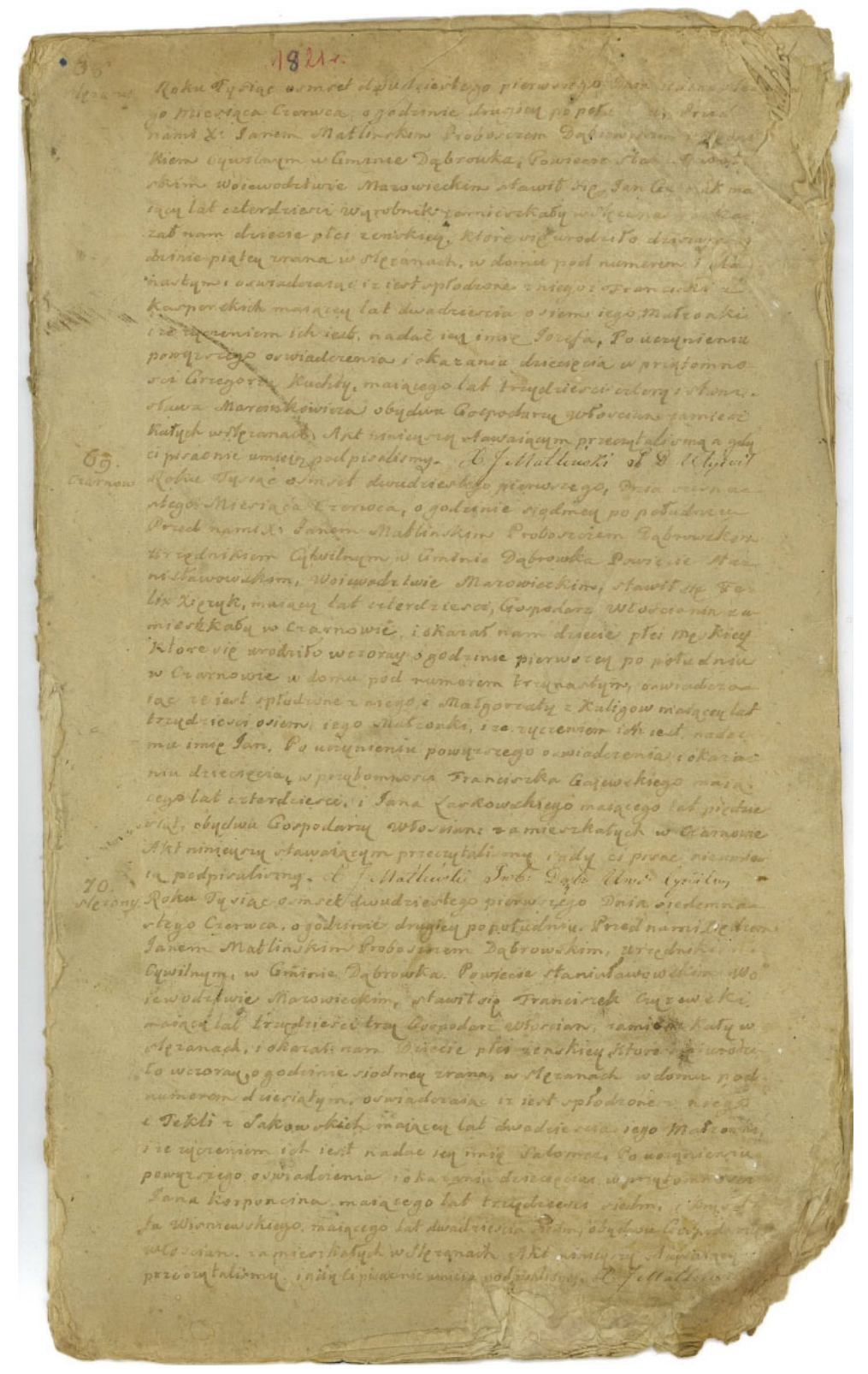

Fig. 1. First page of the preserved passage from the vital records from 1821 


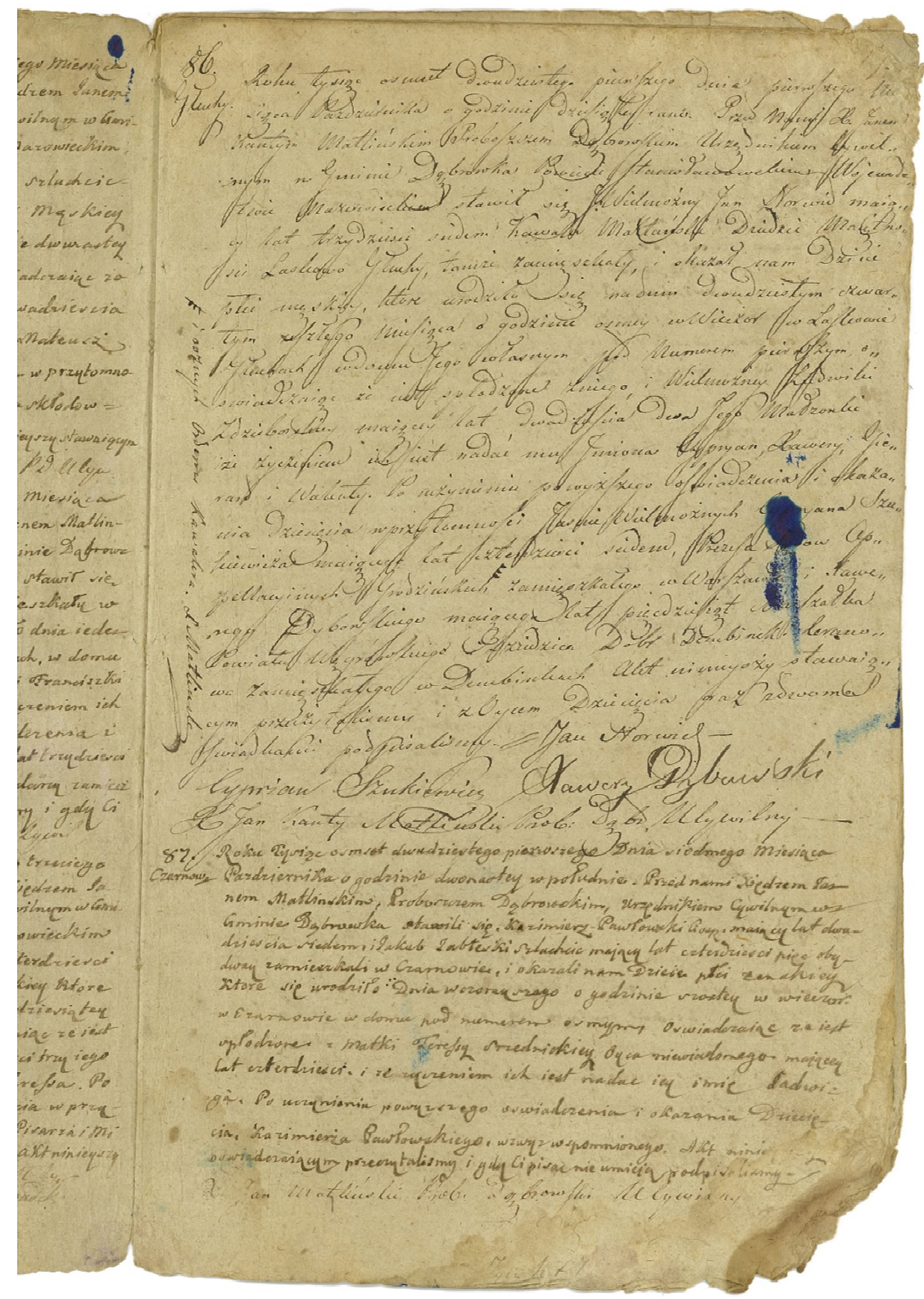

Fig. 2. Cyprian Norwid's birth certificate 


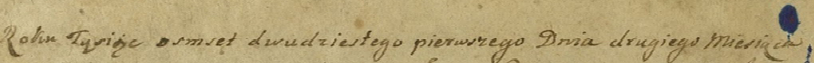

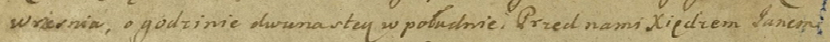

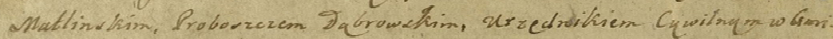

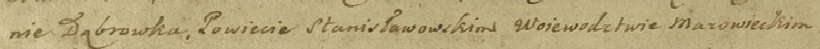

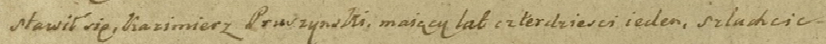

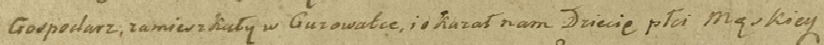

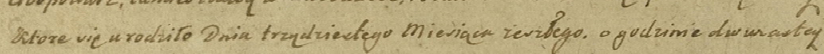

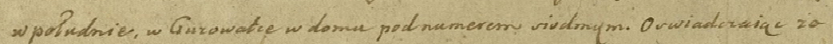

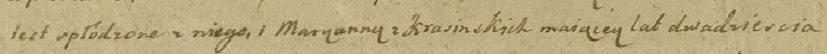

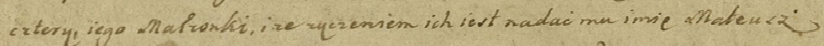

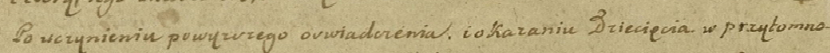

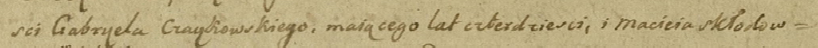

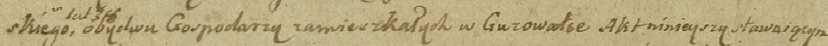

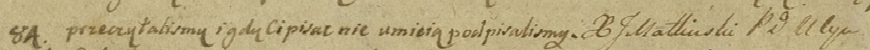

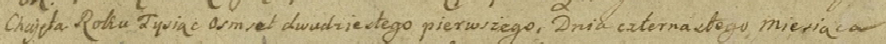

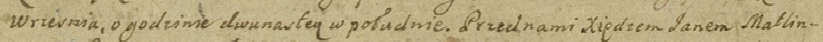

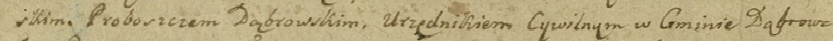

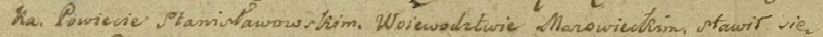

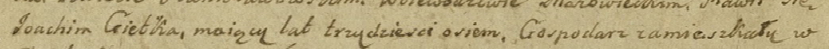

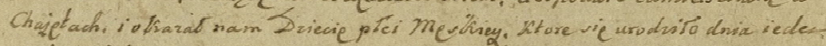

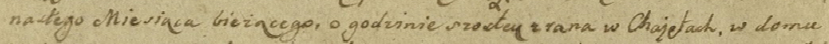

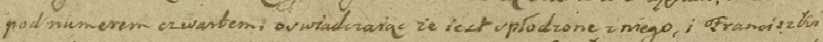
i Myuliveow, maingen Lat dwadriescia pres iego Matronth; ; ze requemien ich

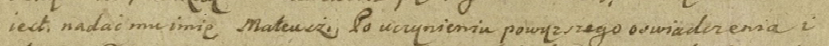

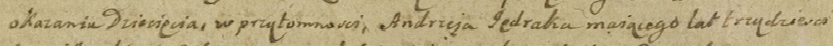

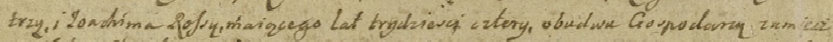

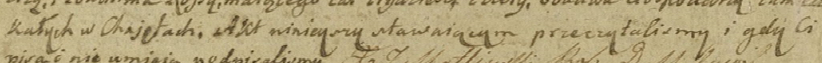

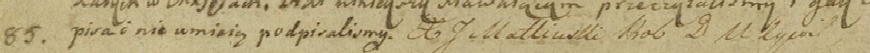

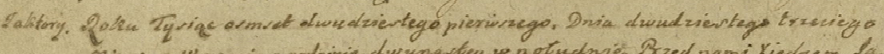

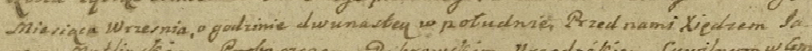

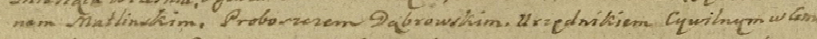

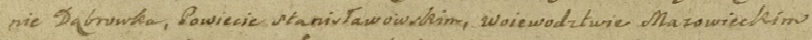

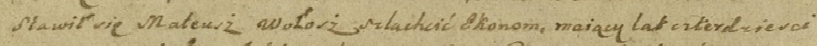

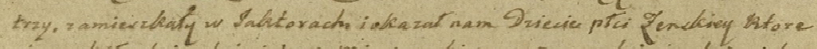

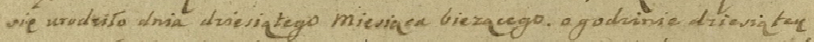

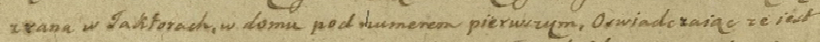

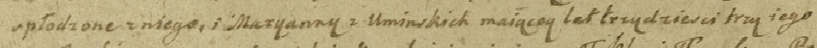

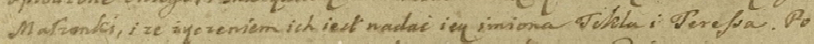

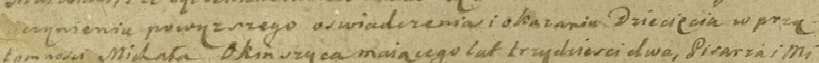

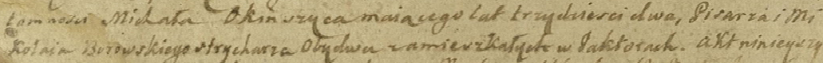

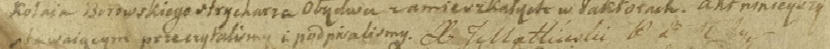

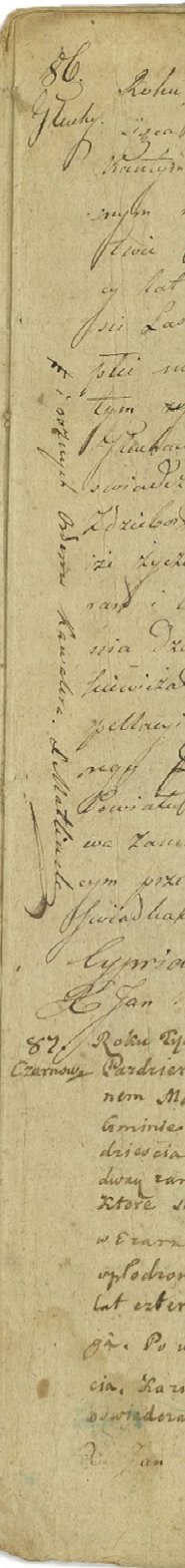

Fig. 3. Opposite page from the vital records signed only by the parish priest 


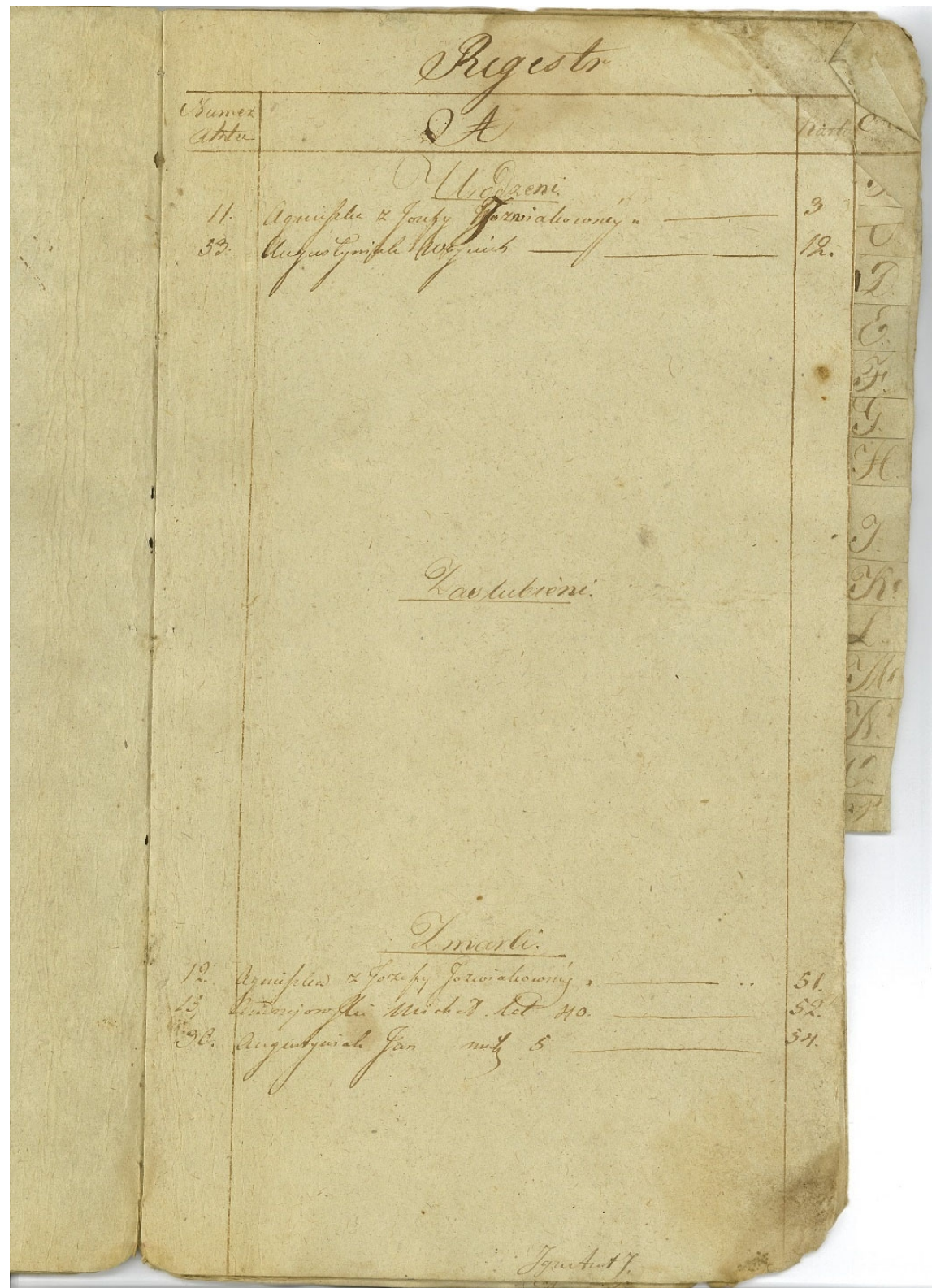

Fig. 4. The first page of the register 


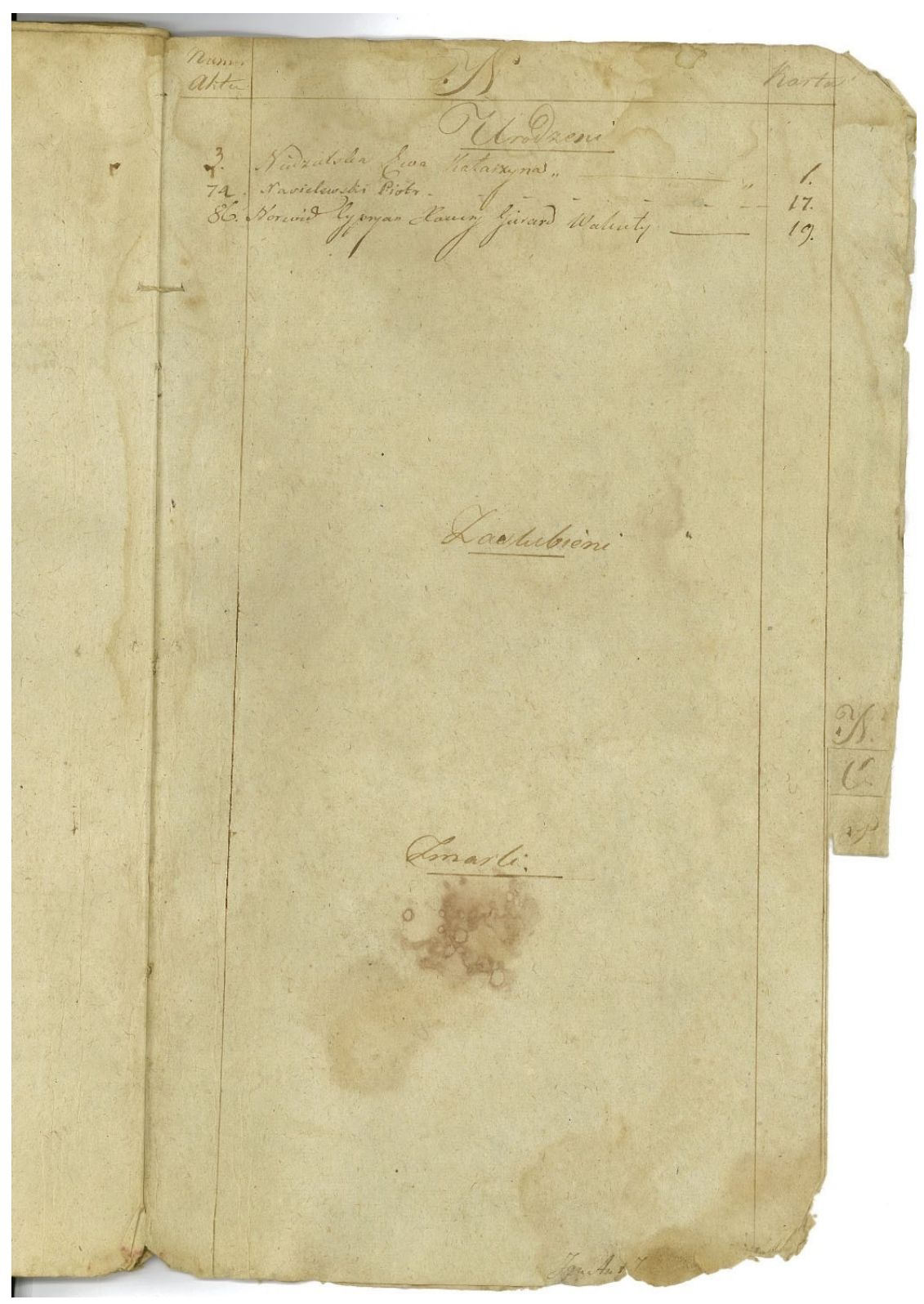

Fig. 5. Page from the register containing the record concerning the poet 